\title{
A theory of institutional change: Illustrated by Dutch city-provinces and Dutch land policy
}

Edwin Buitelaar

Nijmegen School of Management, Human Geography and Spatial Planning, Radboud University Nijmegen, The Netherlands; e-mail:

e.buitelaar@fm.ru.nl

Arnoud Lagendijk

Nijmegen School of Management, Human Geography and Spatial Planning, Radboud University Nijmegen, The Netherlands; e-mail: a.lagendijk@ru.nl

Wouter Jacobs

Nijmegen School of Management, Human Geography and Spatial Planning, Radboud University Nijmegen, The Netherlands; e-mail: w.jacobs@fm.ru.nl

\section{Contact}

Edwin Buitelaar

Nijmegen School of Management

Radboud University Nijmegen

Thomas van Aquinostraat 3

Postbus 9108

6500 HK Nijmegen

The Netherlands

$0031(0) 243611557$

$0031(0) 243611841$

e-mail: e.buitelaar@fm.ru.nl

\section{Acknowledgments}

The authors would like to thank Ton Kreukels, Barrie Needham and three anonymous referees for their comments on an earlier draft of this manuscript. The research for this paper was supported by NWO grant 45004-004. 


\section{A theory of institutional change: Illustrated by Dutch city-provinces and Dutch land policy}

Since the early nineties, planning theory has focused on the issue of institutional change. Not only does institutional change have clear bearings on processes of spatial planning, it is also, increasingly, seen as an object of planning. A core concept in the literature is the juxtaposition of 'institutional design' and 'institutional evolution'. Yet, in understanding processes and the role of institutional change, this dichotomy does not appear to be very helpful. We therefore propose a more encompassing perspective that includes both 'design' and 'evolution' dimensions, invoking various components from theories of policy change, inspired by the work of Kingdon. Our perspective tries to unravel, in particular, why, under seemingly comparable conditions, some cases show substantive institutional transformations while others do not. The paper briefly discusses two cases from the Netherlands to illustrate this point, namely the thwarted process of establishing city regions within the scalar fabric of territorial governance, and some instrumental changes in land policy in the Netherlands.

\section{$1 \quad$ Introduction}

In planning theory, following the new institutionalist debates in sociology, economics and political science, much attention has been given lately to institutions, both formal (like norms and rules) and informal (like values, 
conventions and codes of behaviour) institutions. In line with this, institutional change has also been a central element in the debates in planning theory since the early nineties (see for instance Bolan, 1991; Gualini, 2002; Healey et al., 2002; Innes, 1995; Alexander, 2000). According to Innes (1995), the essence of planning is institutional design. In line with this, much is written on building institutional capacity in recent years. The goal usually is to find ways in which agents can unfold their creative practices to adapt to changes, within collaborative processes, in order to break through the institutional pathways and their structural force (Healey et al., 2002; Healey, 1998).

However valuable, it puts the main emphasis on the normative side of institutional change, in other words, how it could and should be done. What is rare in the field of planning, is a plausible theory of how institutional change actually occurs. Why and when do institutions change? Some (e.g. Gualini, 2001) prefer to think in a dichotomy in which design is set against institutional evolution or building. We want to go beyond the often raised dichotomy of design versus evolution. Although our perspective might be applicable to institutional change in a broader sense, here we confine ourselves to institutions that are relevant to planning.

This paper is structured as follows. Section Two illuminates four perspectives on institutional change, followed by a synthesis on institutional change (section Three). After the framework has been established, two 
empirical examples will be discussed to illustrate how it can structure our thinking on institutional change. But not only do they serve as an illustration of the conceptual framework, vice versa, this framework has benefited from and been informed by the empirical knowledge on the changes in practices and structures in regionalisation and land policy.

Both examples come from the Netherlands. The first example deals with the attempts to anchor (i.e. institutionalise) the city-province into (and therewith change) the Dutch state structure (section Four). The second example regards the convention of active land policy by Dutch municipalities, and the changes within that convention (section Five). We have chosen two quite different cases, in order to illuminate the applicability of the framework. One difference is the state of institutionalisation, which is regarded as the process in which behaviour and discourses become anchored (a more elaborate treatment follows). The city-provinces have not been formally institutionalised (yet) because the state structure shows great inertia. In the case of land policy, we see the opposite: here active land policy has become institutionalised (i.e. became a generally acknowledged convention) since the second World War and follows a certain path of development, leading to all sorts of attempts to reinforce it. Another difference is that active land policy is an informal institution, whereas the city-province comprises formal institutions. A third difference is that active land policy is used to achieve spatial policy goals, whereas the city-province 
serves political-administrative goals in more general terms in the light of territorial governance. But both cases are examples of institutional change in the way space is administratively organised. Finally, section Six concludes by discussing how lessons drawn from the cases bear on our framework of institutional change.

\section{Institutional change: beyond the design versus evolution dichotomy}

Do institutions stem primarily from intentional design or from unintentional, gradual processes of solidifying? The literature on institutional development has brought (at least) forth different views on this issue. Some approaches tend towards an organic interpretation, while others acknowledge the role of intentional shaping and creation of institutions, that is, of institutional design. This section will first give an overview of the main perspectives on institutional design versus evolution. Four perspectives are of particular interest for our discussion here, namely the emphasis on institutional design, the institutional and evolutionary economists' emphasis on selection through efficiency, North's account of path dependency, and the sociological perspective on institutional change.

One of the major advocates of the 'institutional design' approach in the literature is Bromley (1991), who regards institutions explicitly as 'relations' that can be deliberately created. In other words, they stem from 
institutional design. Alexander (2002a, page 1) defines institutional design as " $[\ldots]$ the devising and realization of rules, procedures, and organizational structures that will enable and constrain behaviour and action so as to accord held values, achieve desired objectives, or execute given tasks." In his book on property rights, Bromley (1991) sets out that property rights are not, like it is argued by for instance John Locke, 'natural rights', but are created by collective action. Bromley regards the property rights regimes as 'policy instruments' that can be applied to serve certain policy objectives, as for example with the British nationalisation of development rights in 1947, which meant that all development became subject to approval by the government (which delegated it to the local planning authorities).

The problem with such a strong emphasis on design and therewith an instrumentalist view on institutional change is that it cannot explain why, out of a large number of alternatives, particular institutions are chosen in particular times and places while others are not, and why only certain institutions survive in the long term. To avoid an overly voluntaristic view, therefore, a theorisation of institutional development and selection is required.

In the second perspective, it is assumed that institutions evolve through organic variation and are selected on the basis of their efficiency. This vision of institutional change draws from insights of Hayek (1960), and 
evolutionary economists. The basic setting for facilitating both variation and selection is the market in which individuals rationally pursue their selfinterests (see for instance Webster \& Lai, 2003). The market is so effective in inducing variation and efficiency-based selection that there is hardly any scope for comprehensive forms of institutional design, i.e. for 'state planning' interfering with market processes besides the public creation and enforcement of private property rights and basic corrections of 'market failure' (Webster \& Lai, 2003). In the context of land use institutions, for instance, an important capacity of markets is its ability to reassign property rights (so to change institutions) in response to changes in resource value.

The efficiency view has inspired a particular strand in economics that has further explored the development of institutions, namely transaction cost economics (Demsetz, 1967; Williamson, 1985). In this view, institutions evolve to minimise transaction costs, in order to increase economic efficiency. Market proponents (Webster \& Lai, 2003) use the transaction cost argument to defend their thesis that markets, as an assembly of institutions, reduce (spontaneously) the costs of organising a multitude of individual transactions. Yet, critical observers (Hodgson, 1993) were quick to point out that there is no evidence that institutional developments, notably in the field of policy, are leading to higher levels of economic efficiency. The question then arises, what may explain the perseverance of institutions that support inefficient forms of organising and policy-making? 
To explain the efficiency lacuna, institutional economists pointed at a complicating factor in the relationship between transaction costs and institutional evolution. The emergence of particular institutions may not only alter transactions costs, it is also, in itself, subject to transaction costs (Furubotn \& Richter, 1991). Institutional economic perspectives thus took on board a new core element in the explanation of institutional development, namely the role of history. The most prominent contributor to this line of thinking is Nobel Prize winner Douglas North. In his view, "The major role of institutions in a society is to reduce uncertainty by establishing a stable (but not necessarily efficient) structure to human interaction" (North, 1990, page 6). North argues that the "structure for human interaction" also bears on future institutional changes. In other words, history matters. In a world of uncertainty and imperfect information, the history of institutions has a large effect on the way institutions are shaped today. The result is an institutional path, where the direction taken at each crossroads limits the scope for future variation. Past turns thus lock in future development. What is particularly important is the dynamic nature of this path. A certain institutional path generates learning effects, that contribute to either a higher quality of the product or to a lower price (Boschma \& Lambooy, 1999). 
To what extent does a historical perspective assign a role to institutional design? In North's (1990) view some institutions evolve by themselves while others are deliberately created: "Institutions may be created, as was the case the United States Constitution; or they may simply evolve over time, as does the common law" (see for similar statements Scharpf, 1997; Gualini, 2001). Yet the scope of this design is strongly pathdependent, i.e. determined by past experiences, and place-dependent, i.e. determined by geopolitical contingencies. In essence, institutional design comes down to the articulation and advocacy of one of the many options brought up by a particular historical trajectory at a certain place. Institutions thus result from a historical path that is punctuated by acts of purposeful design (Weimer, 1995).

While, by taking into account the costs of institutional change, North and other historical economists have qualified the basic efficiency criterion applied by institutional economists, their perspective remains strongly rooted in an approach that features the economic instrumentality of institutions. It is this instrumentality that is challenged by more critical approaches. In his seminal publication 'Economics and evolution: bringing life back into economics', Hodgson (1993) criticises economic instrumentality for ignoring power inequalities and argues that institutions will persist if they serve the actors or coalitions in power, independent of the question whether they are efficient or not. Yet, while assessing institutional 
change in political rather than economic terms, even power-based approaches tend to adopt an instrumental view of institutions, by explaining their development in terms of the way powerful actors shape institutions to achieve a desirable 'mobilisation of bias' (Schattschneider, 1960). A problem with this approach is that it leads to the expectation that power asymmetries would be able to reproduce and even strengthen themselves by the manipulation of the 'rules of the games', something which does not seem to be generally endorsed by the recent history of, in particular, the Western World (Weimer, 1995, page 7). There are many examples, as exemplified by processes of democratisation and social emancipation, where institutional change has been induced by actors and through processes initially operating at the margin of societal arenas.

How can we account for the fact that institutional change may not be accompanied by increasing efficiency? How can we explain that institutional change does not seem to exacerbate power asymmetries? The fourth perspective, drawing from sociological thinking, sheds light on these questions by rejecting an instrumentalist perspective on institutional change and putting forward an alternative approach.

Many sociological institutionalists replace the means-end rationality of the efficiency approaches, and the 'mobilisation of bias' perspective of powerbased approaches, by drawing attention to the symbolic and cognitive 
dimensions of institutions and institutional change (March \& Olsen, 1989). Institutions have cultural significance. They embody particular values instead of just serving them instrumentally. Institutions provide meaning and frames of reference that help to orientate and steer behaviour.

From this sociological perspective, institutional change is guided not by a technical rationality that considers institutions as means leading to certain ends, but by a social rationality based on interpretation and values. Institutions are devised and adopted principally because of their social appropriateness and legitimacy. Institutional development follows a 'logic of social appropriateness' rather than a 'logic of instrumentality' (March \& Olsen, 1989). This does not mean that institutions cannot have an instrumental value: instrumentality can be socially highly appropriate and legitimate. This process becomes self-reinforcing, when institutional development nurtures the development of frames of references and values that further endorse the institution.

In a sociological perspective, hence, values and views on desired objectives are not considered as external 'givens' but as factors internal to institutional development. Yet this poses serious theoretical, analytical and normative challenges. A key element in institutional development is the process of institutionalisation, which may be defined as "a process in which fluid behaviour gradually solidifies into structures, which subsequently structure the behaviour of actors" (Arts \& Leroy, 2003, page 31, translation 
ours), and which is accompanied by the development of particular discourses, power and resource relations. What makes analysis of institutionalisation problematic is that the process of institutionalisation itself is influenced by preceding solidifications of structures, which leads to the conundrum of infinite regress in which institutions are revolving as both explananda and explanans (Hodgson, 1993). Institutionalisation is in itself a process guided by institutions. When applied to planning, Gualini (2001, page 55), describes this problem in terms of 'the duality of planning' in which planning is at the same time 'an institutionalised practice' and 'a factor of institutionalisation'.

What does such a perspective mean for our understanding of institutional design? The crux of this sociological view of institutional design is that institutional design is not seen as opposed to institutional evolution, but as an integral part of this evolution. Institutional development is often triggered by the instrumental wish of (collective) agents to 'get the institutions right' by attempting to strengthen their effectiveness, efficiency, resource base, and transparency, amongst others. Yet, through the social, political and technical reality in which such initiatives are taken, they quickly become twisted and entangled in complex webs of social interactions. Institutional design thus turns into what Chase Smith et al (2001, page 42) call 'institutional bricolage', defined as: “the patching together of institutional arrangements from the cultural resources available 
to people in response to changing conditions." A key feature of institutional bricolage is the coming together of different (mainstream and alternative) logics and perspectives. In the view of Linder and Peters (1995, page 133), institutional designing often takes the form of 'tireless tinkering' (p. 133), based on two strands. First, a decisional strand, with emphasis on producing solutions to problems. Second a dialogical approach, with emphasis on the socially embedded process of institutionalisation. The implication is that, in their words, "design will require conscious efforts at changing the cultural as well as ideational elements of the institution as well as its structural elements" (Linder \& Peters, 1995, page 133). In a more precise way, we could perceive the decisional manifestations of institutional design, in which action is justified and advocated on the basis of a 'logic of instrumentality' or a 'technical rationality', as a key cultural resource in the process of institutional bricolage. As the daily stream of advisory reports and technical consultations accompanying the processes of institutional design shows, discursive 'proofs' of instrumentality are in fact a major factor in the 'logic of social appropriateness' that drives institutional development.

\section{Towards a model of institutional change}

What remains a conundrum is the extent and nature of autonomy enjoyed by agents pursuing institutional change, the so-called 'bricoleurs'. Some authors put considerable faith in the transformative capacity of agents. De 
Jong (1999, page 52), for instance, defines institutional design as “... the deliberate and methodically structured adaptation of a system to meet external quality requirements by manipulating elements and relationships." There are two factors that may, in particular, contribute to such transformative capacity. First is the capacity of agents and organisations driving institutional change to gain societal recognition, trust, legitimacy through building identity, leadership, and operational competence (Boin \& Kofman-Bos, 2003), things, as we will see, that were lacking in the first case (Section Four). Second is the capacity of the 'system' to learn and act upon this learning, i.e. the capacity for institutional reflection. Institutional design requires a capacity for 'triple-loop action learning' (Gualini, 2001, page 37), which makes processes of institutionalisation and the way they are socially and institutionally embedded subject to critical cognitive reflection and action. The question then is to what extent are such organisationaltransformative and learning capacities defined, in the end, by broader traditions, values and discourses, and their historical development? What is the balance between, or perhaps, articulation of, path-dependency and the 'path creating' action of 'bricoleurs' engaging in institutional design?

In their discussion of institutional change, Burch et al (2003) introduce various ideas that may help to shed light on the role of 'bricoleurs' versus that of structural factors, in inducing what they call 'rupture' in an 
institutional path. In line with historical institutional approaches, the authors distinguish periods of 'rupture' from periods of stability. It is during 'rupture' that there is scope for 'path breaking' and 'path creating' forms of action. Yet, where most historical institutionalists consider rupture as primarily externally triggered (Hall \& Taylor, 1996), notably through crises, Burch et al argue that many incidences of institutional change are actually internally driven. The accumulation of gradual pressure for change from within or from the margin, in the form of critical reflection by agencies, proposals for institutional (re)design, and promotional action, may produce incremental change.

In the terminology of Burch et al (2003), when there is sufficient pressure, whether internally or externally driven, a 'critical moment' for change arrives. Existing institutional structures become questioned and emerge on the agenda. There is scope for internal as well external actors to jockey for new positions. If the opportunity is grasped and changes are realised, the critical moment turns into a critical juncture encompassing a break with past patterns, inducing the overhaul of 'discursive hegemonies' (Hajer, 1995, page 59), through which institutional transformations may occur' $^{1}$. Distinguishing 'critical junctures' from 'critical moments' may thus help to explain how institutional transformations actually take place.

\footnotetext{
${ }^{1}$ Following this logic, our approach is close to what Schmidt (2005, forthcoming) would call discursive institutionalism. She adds this type of institutionalism to the often made
} 
However, Burch et al do not provide an approach for identifying and analysing the conditions under which, after a critical moment has emerged, a critical juncture is reached. It is here that we propose to introduce another conceptual step in our explanatory framework, based on Kingdon's (1995) theory on policy agenda setting. Kingdon conceptualises the critical condition for policy transformation in terms of the concurrence of three 'streams' of development. These streams are (a) the societal problems that are conceived important, (b) the policy solutions at hand (e.g. suggestions of institutional (re)design) and (c) political endorsement and action. The matching of the three streams results in a 'window of opportunity', which is the critical juncture in the words of Burch et al (2003).

\section{Figure 1: A model of institutional change}

The addition of Kingdon's condition for policy transformation to the earlier exploration results in a staged approach as depicted in Figure 1. The starting point is an existing institutional arrangement, accompanied by a discursive hegemony. Again, two interrelated developments affect the hegemonic discourse and therewith the position of the institutional arrangement and make it malleable. First, the stream of reflection, alternative ideas 
(solutions) and actions of the institutional bricoleurs that challenge the present stable situation; second, external societal developments, notably those that put the present institutional arrangement under strain. The first window of opportunity opens when one of these developments, or a combination of both, exerts sufficient pressure, as to open up the discursive arena. So it is through a change in discourses and discursive hegemonies that institutions become challenged. What might also happen is that although an institutional arrangement is no longer supported by a hegemonic discourse, it might persevere because external and internal pressures are not strong enough to create a critical moment (Pestman, 2001). Those could be institutions that are neither functional nor dysfunctional.

When the existing institutional arrangement is successfully challenged, the result is a critical moment in which there is scope for opponents to jockey for new positions and for alternative ideas to gain support. Yet whether such a change is really effectuated depends on the opening of a second window of opportunity: the critical juncture. So one condition for this window is an institutionally, politically and discursively defined critical moment, comparable to Kingdon's political stream. In addition, the window requires the alignment of powerful alternative ideas and problem perceptions, corresponding to Kingdon's other two streams. For our purpose, relevant ideas are especially those centred around 
institutional (re)design. Problem perceptions are influenced, on the other hand, by the way agents translate perceived societal developments into problems that require attention. What is especially important in this stage is that the matching involves a particular confluence of the problem and solution streams, out of possibly many alternatives. When the opening of the window is followed by a consolidation of a particular problem-solution combination, a critical juncture is reached resulting in institutional transformation.

It is important to note that our staged approach, like its components, should be read as an analytical rather than a historical model. In the messy reality of institutional change, the two windows of opportunity, as well as the various streams, tend to be entangled in complex, contingent ways. Yet, through its analytical distinctions and the notion of matching, however stylised, we hope to provide a better understanding of how actions aiming at institutional design are positioned within a perspective of institutional evolution. It is against this background that we will discuss two empirical examples of how institutions change or continue, and what are the driving forces behind that. The examples we use come from the Netherlands. We will explore the institutionalised practice of active land policy in the Netherlands. But first, we illuminate the attempts to institutionalise cityprovinces, particularly in the Rotterdam region. 


\section{Territorial governance and the failure of the Dutch city-province}

Despite the fact that the Netherlands emerged as a union of independent provinces, regional governance plays a limited role nowadays. From 1912 onwards, but especially in the post-war period, there have been manifold attempts to strengthen regional governance. These attempts generally fall under two basic categories, (1) the creation of a new level of regional governance and (2) adaptation of provincial governance by designing and institutionalising the city-province. Regional governance has been advocated on the grounds that many problems, including economic development, traffic congestion and urban social and housing problems required a regional focus. Yet, the various attempts met quick resistance and only a few city-regional governance structures managed to survive. Below we will deal with the process of regionalisation in the Netherlands, with special attention to the rise and fall of the Rotterdam city-province as being the most outstanding and advanced case in this respect ${ }^{2}$.

After various attempts in the pre-war and early post-war period, the call for urban regional forms of government re-emerged in the Netherlands during the 'glory days' of the central welfare state in the late 1960s. Like elsewhere

\footnotetext{
${ }^{2}$ Another interesting case in this respect is the thwarted development of the Amsterdam metropolitan area (Alexander, 2002b).
} 
in Western Europe, the belief arose that territorial spill-overs such as uneven economic development and unequal distribution of resources could be tackled by the installation of a metropolitan government with strong planning powers for the supply of welfare provisions (Lefèvre, 1998), an idea that still holds up today (Herrschel \& Newman, 2002; Jensen \& Richardson, 2004). Using Kingdon's terminology, there was strong confluence between external developments (problem perception) and institutional reflections (solutions) opening up the discursive arena bearing on territorial governance.

The critical factor for enhancing and benefiting from the emerging critical moment, accordingly, rested with the third stream, i.e. political-institutional endorsement and action. How and when would political and institutional conditions be sufficiently tuned to accommodating a fundamental change in the country's territorial governance structure? This presents a typical case of 'bricolage' wavering between 'path dependence' and 'path creation'. Basically, the impact of 'path dependence' is manifested through the fact that the Dutch state structure of today still harks back to the constitution that was drawn up under the supervision of the liberal Johan Rudolf Thorbecke in 1848 . The new constitution settled the division of power between the different tiers of government, in what is nowadays called the 'House of Thorbecke'. The House of Thorbecke is an inheritance of the French 
Napoleonic system with a three-tier administrative-territorial structure, typical for unitary states (Zweigert \& Kötz, 1987; Newman \& Thornley, 1996), consisting of central government, provinces with primarily administrative tasks, and municipalities enjoying a certain level of autonomy. Where changes have occurred within this model of territorial governance, it mainly involved changes in size and numbers. Newly reclaimed land resulted in an additional province (Flevoland). More significantly, the number of municipalities was reduced from an initial 1200 to 489 in 2003, as a result of a continuing process of annexations and amalgamations. More substantial intervention oriented towards 'path creation' faced two kinds of obstacles. First, calls for adding another tier of government, like between municipalities and provinces, required a change in the Constitution to allow an overhaul in the 'House of Thorbecke'. Second, adaptations fitting within the 'House of Thorbecke' such as the redrawing of the provincial boundaries or the formation of city-regional unitary councils depended on the cooperation of the government bodies involved - national, provincial, ánd municipal -, as well as other local organisations and the public. The impact of these obstacles will be further detailed by examining the attempts to create a city-province of Rotterdam.

Initially, the Rotterdam case presented a story of promising institutional change(Flierman, 1994). The critical moment emerging in the 1960s was 
grasped and turned into an initial juncture by the establishment of the Rijnmond Authority (Openbaar Lichaam Rijnmond) in 1965. Rijnmond Authority, of which the governing members were directly elected, was principally charged with coordinating, planning and implementing policies concerning port and related business parks development (plus business location on these sites), housing, transport and infrastructure, open air recreation and environment. To accomplish this, Rijnmond received a lump sum funding from the central government budget plus open funding from its constituent municipalities. The representatives were directly elected. Regarding its competencies, the body faced a persistent tension between its status as a supra- and inter-municipal body.

Yet, soon after its establishment, conflicts started to arise between the municipality of Rotterdam and the Rijnmond about the interests of the seaport, which paralysed the governance and integration process (Flierman, 1994, p 265-266). In general, municipalities fiercely resisted what was conceived to be a rather technocratic and top-down imposed Rijnmond. Neighbouring municipalities, in particular, feared the loss of political weight and power (Flierman \& Pröpper, 1997). Confronted with a persistent battle with municipalities on the division of competencies, the institutional response was to step back from the 'centralised' Rijnmond model, and to move to more 'bottom up' model of regional collaboration based on intermunicipal voluntary agreements (invoking the so-called WGR, 
Common Provisions Act). So, in 1985, Rijnmond was converted from a public authority into a voluntary collaborative organisation 'OOR' (Overlegorgaan Rijnmondgemeenten). Governed by a regional council chaired by the mayor of Rotterdam, OOR was composed of delegate council members from its constituent municipalities.

Soon, however, the case for a regional administrative tier returned on the political agenda with the strategic documents 'Grote Steden, Grote Kansen' (Big Cities, Big Chances) by the Commission Montijn (1989) and 'Van de Stad en de Rand' (Cities and Edges) by the Scientific Council of Governmental Policy (Wrr, 1990). These documents addressed the socialeconomic and financial problems faced by the big cities such as Amsterdam and Rotterdam at that time. More specifically, the call was repeated to internalise the spatial spill-overs such as traffic congestion, uneven economic development and free-riding behaviour of suburban communities, which are inherent to large urban agglomerations. Processes such as European integration and increased international competition between large urban centres also enhanced the perception of a 'regional governance gap' (Schobben, 1995) in the Dutch administrative-territorial structure, again signalling the relevance of the problem-solution match enabled by regionalisation. Central government followed the advice of the Commission Montijn with the official document 'Bestuur op Niveau' ('Governance at the 
Right Level') of 1989, in which the central government proposed the institutionalisation of city provinces, framed within the existing 'House of Thorbecke'. So both external societal developments and institutional reflections at the national launched another critical moment for institutional change.

Political support at the regional level, however, remained ambivalent. Opposing yet another top-down imposition, representatives of the municipalities in the Rotterdam area reacted collectively with their own Strategic Vision OOR (Strategische Visie Overlegorgaan Rijnmondgemeenten) for an urban regional governance structure in 1991. In spite of the traditional different interests of the central city and its suburbs, both parties initially found common ground in cutting the province of South Holland out of the Rijnmond-area. This bottom up approach included a straightforward institutional design: the installation of a consolidated city-province with a directly elected government independent of the province of South-Holland but with the same competencies provided by law or lex specialis.

Like before, the history of this attempt showed the 'bricolage' induced by the way the desire to bring about more fundamental changes was thwarted by the legacy of the past. Initially, the proposal made by OOR representatives was to install a metropolitan government as a complete new (and fourth) administrative tier, but this was considered as constitutionally 
too complex and was blocked by the Ministry of Home Affairs. Therefore the proposed urban regional body was given the status of province (Derksen, 1996). In order to keep all parties on board, the design also included a rather revolutionary idea, namely the abolition of the municipality of Rotterdam by splitting it up in several new municipalities. Splitting up Rotterdam served two purposes. In the eyes of the key 'bricoleurs' , the so-called 'Gideongang' led by the mayors of Rotterdam and Krimpen aan de IJssel, Peper and Bruins Slot, weakening the institutional and political strength of the City of Rotterdam would ensure the support of the suburban municipalities for the city-province. Also, the cityprovince would be more powerful and effective when it has no political competition from a large municipality. Splitting up the central city was the key factor in the initial success of the regionalisation process and the Rotterdam-model served as an example for other proposed urban regions in Amsterdam and the Hague.

While regional support thus started to consolidate, the tide changed after the national and local elections of 1994. All seemed promising in 1994 when the central government adopted a so-called 'Framework Law for Administrative Change' (Kaderwet Bestuur in Verandering) which allowed seven urban regions to transform into city-provinces ${ }^{3}$ within eight years

\footnotetext{
${ }^{3}$ Besides Rotterdam, the framework law included the urban regions of Amsterdam, the Hague, Utrecht, Enschede-Hengelo, Eindhoven-Helmond and Arnhem-Nijmegen. The Framework Law is a special form of intermunicipal collaboration facilitated by the
} 
time. However, in the national elections of 1994 the pro-regional coalition of Christian Democrats and Labour Party lost power. The new coalition between the Labour Party and the liberal parties VVD (conservative) and D66 (progressive) was less keen on large consolidated metropolitan governments. Moreover, also on the local level coalitions shifted. Local civil servants started to worry about the task of administrative reorganisation (involving in total 40.000 positions). They also feared breaking up the existing municipality would hamper their careers prospects (Van Der Meer \& Van Hoek, 1999). Similarly, the suburban municipalities, especially the weaker ones, were afraid that they would be overshadowed by Rotterdam (or what would be left it) and lose authority over their own territory. In addition, local authorities were also wary of a regional authority that would be much more proactive and authoritative than the existing provincial administrations used to be. This fear was compounded by a continuing dispute about the division of competencies between the local and regional level, and a lack of local leaders who could act as transformative agents (Van Der Meer \& Van Hoek, 1999). A final institutional opponent was the province, that saw its jurisdictions, plus accompanying resources and political influence, erode.

Common Provisions Act (WGR), in which participating municipalities commit themselves to a joint coordination of at least four statutory policy domains: spatial planning, economic development, transport and environment. 
At the same time, local-interest parties started to win a lot of support at the expense of the 'Gideongang' (Koppenjan \& Zaaijer, 1997). These opposition parties feared the break-up of the main city would undermine its strong identity, sense of community and its (cost) effectiveness: “The Stadspartij [City party], backed up by local radio and television, highlighted that to split up the municipality would mean higher costs ('10 new mayors have to be paid') and a weaker city. The mayor was portrayed as a kind of traitor who wanted to rob the citizens of their city. With the help of generous (local) media attention, and - as some argued- untrammeled by links with national politics and ideology, the Stadspartij was one of the few to wage a successful, populist and protest, campaign. The local media decided to help local David in his battle with the national Goliath" (Van Der Meer \& Van Hoek, 1999, page 17). Consequently, local interest parties in Amsterdam and Rotterdam initiated (non binding) referenda in which the citizens could vote whether or not they favoured the plans to split up the municipality. Not surprisingly, the outcome proved to be disastrous for the process of regionalisation. In both cities more than 90 percent of the voters rejected the proposals. These dramatic results ensured that the second window of opportunity remained closed for the proposed radical institutional reforms of the Dutch administrative-territorial structure.

In the end, history repeated itself once more. Instead of establishing strong city-provinces, the municipalities of the seven designated urban 
regions started their non-voluntary co-operation under the Framework Law in 1995. After almost ten years, the results of these 'weaker' designs of regional governance are mixed (Ipo, 2002). In most cases, a regional land policy and regional financial exchange have not been realised; there is weak public affinity; a lack of decision-making transparency and persistent tensions with the provinces. On the other hand, all the municipalities within the urban regions showed their willingness to continue their non-voluntary co-operation through extension of the Framework Law, which might indicate that the urban regions are becoming more and more institutionally embedded. What remains a strong factor is that municipalities continue to be confronted with spatial problems that, as they also realise themselves, can only be solved through regional forms of governance, both in a more functional and democratic sense.

Why did the attempts to found a regional governance structure fail? The case presents a clear indication of a persistent external pressure, which, when accompanied by an extended process of institutional reflection and political mobilisation, resulted in successive 'critical moments'. Moreover, various new institutional designs that appeared to provide solutions matching the 'regional' problems at hand made it to the first stage of actual implementation, close to approaching a 'critical juncture'. That, in the end, such junctures failed to happen has two general causes. First, attempts to 
genuinely (i.e. constitutionally) modify the 'House of Thorbecke' by adding an additional tier of governance created its own resistance, both institutionally and politically. So, while the political-institutional stream generated sufficient support for setting institutional change on the agenda, this was not followed up by an endorsement of the wider consequences carried by such change. Second, more focused resistance erupted against particular forms of institutional designs involving either the partial submergence or break-up of local authority. Since no 'strong' design managed to be successful (Schaap, 1997), one had to resort to 'weak' designs that were largely accommodating the existing situation. The strengths of the critical moments thus stands in marked contrast with the unattainability of critical junctures. In other words: "[t]he Dutch case may illustrate the frustrating experiences with functionally brilliant government policies which are not rooted very well in the underlying institutional state structures and the deeper socio-cultural developments within society" (Toonen, 1998, page 149). Indeed, one may wonder whether, change in the country's territorial governance can be brought about by internal dynamics alone, as suggested before. It may well be that he robustness of the House of Thorbecke means that a modification of territorial governance, despite continuing emphasis on the need for, and benefits of, change, will only materialise in the Netherlands under specific conditions such as occupation by a foreign power or a lurking revolution (Hooghe \& Marks, 2001). On the 
other hand, no institutional set-up is permanent and it will be only a matter of time before new critical moments will open the windows of opportunity for 'bricoleurs' to manipulate the path of institutional evolution, perhaps with more success.

\section{$5 \quad$ Land policy in the Netherlands}

Many municipalities in the Netherlands pursue an active land policy, which in general involves land assembly and land development by the municipality, after which it often sells off the land for development by private developers or housing associations (see e.g. Needham, 1997 for a description of Dutch land policy). This tradition has persevered for over a couple of decades now (De Kam, 1996, page 222). After World War II, a massive programme for subsidised housing that had to be implemented, for which the government took the initiative. The result of this programme is that the Netherlands has the highest percentage of social housing in Western Europe. Active land policy by municipalities was necessary to implement this programme.

Nowadays, the percentage of social housing is decreasing and the building task is far smaller than it used to be in the sixties and the seventies. However, active land policy has retained its importance. One could say that after World War II the institutionalised practice of active land policy has always been supported by a hegemonic discourse, i.e. active state 
involvement in the production of space, despite the emergence of other discourses, like privatisation, since the eighties like in many other countries. Municipalities stick to active land policy primarily for two reasons. The first reason is the grip the municipality can have on spatial development by using active land policy. In general, the planning system as laid out in the Dutch spatial planning act (WRO) and housing act does not provide sufficient means to achieve the ambitions of the local government. In a way, it is a negative system that prohibits some land use and hence allows other uses. To implement policy and achieve the ambitions a more active strategy is needed.

The second reason is the financial benefit the municipality can make out of this active policy. With active land policy, the financial profits in the development process can be collected by the municipality, instead of 'leaking away' to developers and housing associations. In addition to the financial benefits, the municipalities can recoup plan costs and the costs of services like public space, social housing and infrastructure. Unlike the English planning system with its planning obligations or the American growth management with its concurrency (a 'pay-as-you-grow' strategy), the Dutch system is not capable of recouping the above mentioned costs. Again, in the Dutch system certain land uses can only be prohibited, nothing can be imposed. Therefore, municipalities use active land policy. After the 
land has been developed, it is often sold off with conditions on future land use. This can give municipalities far-reaching control over development.

One could say that active land policy has become a convention, or an informal institution in North's words. It is taken for granted by both municipalities and developers ${ }^{4}$. One good example of the tradition of supplying serviced land by the municipality is the provision of land for industrial estates. In the Netherlands, there is an oversupply of land for industrial estates, i.e. beyond efficient allocation of resources (Needham \& Louw, 2003). This results in comparatively low land prices for commercial use. This is also good example of the statement earlier made that institutions do not necessarily move towards efficiency.

In 1993, the national government published the Fourth Report on Spatial Planning Extra (Vinex), in which it proposed extension areas (mainly greenfield locations) for urban growth. The local governments faced a problem they were hardly familiar with, namely an emerging involvement of and the co-operation with private developers. After (and even before) the Vinex was published, private developers rapidly started acquiring land on the proposed locations. In many cases they were able to acquire land ahead of local governments. This gave the developers a very

\footnotetext{
${ }^{4}$ Moreover, it is often supported by developers. In the Netherlands, much land is developed by the bouwclaimmodel (building rights model). This model contains a process, in which the developer buys the land and then sells it (paradoxically often for a lower price than it was bought) to the municipality for development, but with a right to build on it after the
} 
strong position. Although municipalities still possess the majority of the land for development, namely $64 \%$ for Vinex locations and $68 \%$ for other locations (Korthals Altes \& Groetelaers, 2000), things have changed. Since then, active land policy by local governments has come under pressure. Private developers are now common players on the land market and in spatial development. Following the framework we set out earlier, we could say that after the Vinex was published external pressure (arrow 1 in figure 1) was exerted (more private initiatives and diminishing dominance of local governments) on the hegemonic practice of active land policy with its instruments, which led to institutional reflection by central government, the main bricoleur in this case, and other stakeholders. The development that has been described has been followed by several measures taken by the state to strengthen the position of local governments.

\section{Development permission}

One example of an attempt by the state to get the institutions right is the proposed development permission ${ }^{5}$. Although at the moment of writing, no decision was taken yet, the process that is building up to that is worth illuminating.

land is developed. The advantage for the developer is the avoidance of risk in the land development stage.

${ }^{5}$ A development permission is separate from a building or planning permission. 
As said before, a municipality (when it owns the land) can impose conditions on the buyer, which is often a private developer or a housing association. Often, these conditions also comprise the recouping of costs made by the municipality, like the costs of plan-making and the costs of public services like parks and infrastructure. If the municipality does not own the land, there are hardly any measures to recoup public expenditures on the development. Then, there are two instruments left that local governments can use. The first is the exploitatieovereenkomst (development agreement). This is a voluntary agreement signed between the municipality and for instance a developer. But because it is voluntary, developers cannot be forced to enter into such an agreement. When an agreement is not reached, costs made by the government cannot be charged back. Then, a municipality can in some circumstances use the baatbelasting (impact fee). But this instrument is rarely used because it is complex and can only be applied in specific circumstances (Van Den Brand, 2003, page 41). Again, due to changed market circumstances, municipalities no longer have a monopoly on the land market and therefore cannot rely solely on the benefits of active land policy. Many agencies (even the developers) feel that there is a need for a good financial instrument based on public law. After the adoption of the Vinex, there have been debates in Parliament, about its execution and the land policy necessary for that, among which was the issue 
of the recovery of costs from developers. A critical moment for change in land policy instruments arose that lasts until today.

As a result of the debates, a consultant (Van Den Brand, 1993) was employed by the Ministry of VROM (which is responsible for spatial policy) to investigate the problem and to propose solutions ${ }^{6}$. The report suggests a development fee (exploitatieheffing), an instrument under public law, that should make it possible to recoup more costs than possible under the existing impact fee (baatbelasting). As the result of this research and the debates in the Parliament, the Ministry of VROM published a document in 1994 (Grondbeleidsinstrumentarium en de uitvoering van de Vierde Nota extra) in which it embraced Van den Brand's development fee. Then the critical moment seemed to fade away slightly, as it took until 1997 (Grondexploitatie in nieuwe bouwlocaties) before the Ministry came with more concrete proposals. The regained political attention was the result of a discussion after the renewed act on pre-emption rights (WVG), to increase the possibilities of active land policy, was passed.

Central to the proposed development fee was that it should be used as last resort, in cases when developers and municipalities failed to come to a 'voluntary' development agreement (under private law). The core of this new instrument was supported by a broad coalition. Among them were two

\footnotetext{
${ }^{6}$ The described process that builds up the presentation of the development permission stems to some extent from Groetelaers (2004).
} 
important councils for government policy related to spatial policy and financial affairs respectively (VROM-raad and Raad voor de Financiële Verhoudingen), but also a wide array of societal interest groups, like the association for municipalities (VNG), the inter-provincial board (IPO), the association of real estate developers (NEPROM) and the association for building companies (AVBB). The Ministry drew a proposal for the amendment of the spatial planning act (WRO). A critical juncture was close to emerging. But before legislation or an amendment is passed by the Parliament and the Senate, it is subjected to scrutiny by the highest advisory body of the government: the Raad van State. Although, the Raad van State endorsed the general goal of the development fee, it raised insurmountable objections against the fusion of public and private law that would be the result of this amendment. The fusion would be caused by making the developments that were not supported by voluntary private development agreements (between developers and municipalities), subject to the public development fee. The negative advice (in 1998) led to the abortion of the amendment of the act, but not to the disappearance of the critical moment for any instrument that could serve the same goals as the fee.

In 2000 Professor De Haan came with a proposal (in line with the decision of the Raad van State) to recoup the costs primarily under public law by suggesting the development permission, which was soon supported by the VROM-raad. Also the NEPROM (the association of real estate 
developers) advocated the idea, and hence a restriction of property rights on the land owned by developers. The reason for this was that developers usually contribute to the municipal plan costs anyway, but that the contribution is often unclear and subject to conflicts between them and local authorities. The development permission would provide more clarity and less uncertainty about the contribution earlier in the development process. Again, the NEPROM reached agreement with the VNG (the association of municipalities) and proposed a permission that serves only as an instrument for plan-cost recovery, better known as the 'narrow' development permission. In 2001, when the national report on land policy (Nota Grondbeleid) was published, the Ministry of VROM also seconded the development permission. But here the consensus stops, as the ideas of the NEPROM and VNG on one end and the Ministry of VROM on the other depart on the reach of the permission, whereas VROM suggests a 'broad' version. In this version, not only plan costs can be recouped, but developers can also be obliged to provide public facilities like infrastructure and green space. Until today, no final decision has been made. The critical moment is still there and there is no question that a juncture will occur, only when and for which version of the development permission remains to be seen. Although the development permission seems to be a break with the path of active land policy, it must be seen as a form of institutional design in the evolution of land policy. Active land policy remains the prevailing land 
strategy, supplemented with an instrument based on public law that can be used when active land acquisition is not possible. More, the history of, and the benefits achieved by, active land policy have had and have an enormous impact on the desire to adopt an instrument under public law that can achieve similar results.

\section{Conclusion}

How can we explain institutional change? We started this paper with distinguishing four perspectives addressing this question. Of the three economically oriented perspectives, North's approach, in which an important role is given to the history of institutions, seems to be the most viable. But this approach too assigns an important role to the economic instrumentality. Institutional lock-in is explained by the difficulties to overcome the high transaction costs of new institutional arrangements and the learning capacity of existing arrangements. The sociological approach focuses on the fact that institutions embody certain values, which might lead to inertia. The cases have shown that institutions once they are institutionalised can be become strongly embedded, like active land policy and the 'House of Thorbecke'. But this does not mean that there is no role for agency and hence for intentional attempts to change institutions. Institutional change takes place as a result of an ongoing process of socialpolitical manipulation and tireless tinkering, a process which can be 
appropriately labelled as 'institutional bricolage'. With the help of the work of Kingdon we have developed an analytical tool to explain institutional change, of which the result has been conceptualised in a two-stage model of change (Figure One). External and internal pressure might force a critical moment. If after a critical moment has been created, problem perceptions and solutions match, and sufficient political-institutional support is mobilised, a critical juncture will develop that leads to institutional change. But not every alternative gains momentum. Institutional change follows a particular path, which under 'normal' circumstances will not be easily abandoned. Through changes in one or more of the streams, particular changes in the institutional arrangements might become possible. The proposed introduction of the development permission in The Netherlands can be seen as a more important 'crossroad' on the path of institutional development. In particular, the proposed use of the development permission as a statutory instrument would imply a break from the conventional way authorities use active market participation. Nevertheless, this (possible) opening of the window is induced by increasing difficulties that local governments experience in pursuing active land policy. The proposals are directed to retain the advantages achieved with active land policy. In addition, they are complementary to active land policy and not meant as a substitute. Again, this backs the notion that past experiences have a major impact on the institutions of today, but they do not determine them. The 
case of regional governance in the Netherlands endorses this phenomenon,

although with a different result. While there has been a continuous, and

historically shaped, pressure for change, institutional rigidities compounded

by political resistance have prevented the successive critical moments to

lead to a consolidation of a regional form of territorial governance.

\section{References}

Alexander, E. R., 2000, Inter-organizational coordination and strategic planning: the architecture of institutional design, in Eds. W. Salet \& A. Faludi Inter-organizational coordination and strategic planning: the architecture of institutional design.(Royal Netherlands Academy of Arts and Sciences, Amsterdam) pp 159-174

Alexander, E. R., 2002a, Acting together: from planning to institutional design, Mimeo (University of Wisconsin-Milwaukee, School of Architecture \& Urban Planning., Milwaukee)

Alexander, E. R., 2002b, "Metropolitan regional planning in Amsterdam: a case study" Town Planning Review 73 17-40

Arts, B. \& Leroy, P., 2003, Veranderingen van politiek, vernieuwing van milieubeleid: klassieke en post-moderne arrangementen (Nijmegen University Press, Nijmegen)

Boin, A. \& Kofman-Bos, C., 2003, The emergence of public institutions: Towards a dynamic theory of institutional birth and development (Department of Public Administration, Leiden University)

Bolan, R., 1991, "Planning and institutional design" Planning Theory 5-6 7-34

Boschma, R. A. \& Lambooy, J. G., 1999, "Evolutionary economics and economic geography" Journal of Evolutionary Economics 9 411-429

Van den Brand, J. A. M., 1993, Grondverwering en baatbelastingnieuwe stijl, een analyse van instrumenten voor het VINEX-beleid. (Van den Brand Advisering BV en dGK, Luyksgestel)

Van den Brand, J. A. M., 2003, "De exploitatievergunning: de gemeente als regisseur" Achtergrondinformatie 39-51

Bromley, D. W., 1991, Environment and economy: property rights and public policy (Blackwell, Oxford)

Burch, M., Hogwood, P., Bulmer, S. J., Caitriona, C., Gomez, R. \& Scott, A., 2003, Charting routine and radical change: A Discussion Paper, Manchester Papers in Politics: 
Devolution and European Policy Series. Paper No 6 (Department of Government, University of Manchester, Manchester)

Chase Smith, R., Pinedo, D., Summers, P. M. \& Almeyda, A., 2001, "Tropical rhythms and collective action: community-based fisheries management in the face of Amazonian unpredictability" IDS Bulletin 32 36-46

Demsetz, H., 1967, "Toward a theory of property rights" The American Economic Review 57 347-359

Flierman, A. H., 1994, Bestuurlijke reorganisatie in Nederland: Rotterdam als proeftuin, in Eds. F. Boekema, H. Van Houtum \& K. Veraghtert Bestuurlijke reorganisatie in Nederland: Rotterdam als proeftuin.(Wolters Noordhoff, Groningen) pp 253-271

Flierman, A. H. \& Pröpper, I. M., 1997, "Bestuurlijke structuur voor grootstedelijke gebieden" Bestuurskunde 6 196-202

Furubotn, E. \& Richter, R., 1991, The New Institutional Economics., in Eds. E. Furubotn \& R. Richter The New Institutional Economics.(J.C.B. Mohr, Tübingen) pp 1-34

Groetelaers, D. A., 2004, Instrumentarium locatieontwikkeling. Sturingsmogelijkheden voor gemeenten in een veranderde marktsituatie. (DUP Science, Delft)

Gualini, E., 2001, Planning and the intelligence of institutions: interactive approaches to territorial policy-making between institutional design and institution building, Urban and regional planning and development (Ashgate, Aldershot)

Gualini, E., 2002, Institutional capacity building as an issue of collective action and institutionalisation: some theoretical remarks, in Eds. G. Cars, P. Healey, A. Madanipour \& Magalhães Institutional capacity building as an issue of collective action and institutionalisation: some theoretical remarks.(Ashgate, Aldershot) pp 29-44

Hajer, M., 1995, The politics of environmental discourses, ecological modernization and the policy process (Clarendon, Oxford)

Hall, P. A. \& Taylor, R., 1996, "Political science and the three new institutionalisms" Political Studies 64 936-957

Hayek, F. A., 1960, The constitution of liberty (Routledge \& Kegan Paul, London)

Healey, P., 1998, "Building institutional capacity through collaborative approaches to urban planning" Environment and Planning A 301531 - 1546

Healey, P., Cars, G., Madanipour, A. \& Magalhães, C., 2002, Transforming governance, institutionalist analysis and institutional capacity, in Eds. G. Cars, P. Healey, A.

Madanipour \& Magalhães Transforming governance, institutionalist analysis and institutional capacity.(Ashgate, Aldershot) pp 6-28

Herrschel, T. \& Newman, P., 2002, Governance of Europe's city regions: planning, policy and politics (Routledge, London) 
Hodgson, G. M., 1993, Economics and evolution: bringing life back into economics (Polity Press, Cambridge)

Hooghe, L. \& Marks, G., 2001, "Types of Multi-Level Governance" European Integration online Papers (EIoP) 5

Innes, J. E., 1995, "Planning theory's emerging paradigm: communicative action and interactive practice" Journal of Planning Education and Research 14 183-189

IPO, 2002, Op schaal gewogen. Regionaal bestuur in Nederland in de 21 ste eeuw (Interprovinciaal Overleg, Den Haag)

Jensen, O. B. \& Richardson, T., 2004, Making European space: mobility, power and territorial identity (Routledge, London etc.)

De Jong, W. M., 1999, Institutional transplantation: how to adopt good infrastructure decision-making ideas from other countries? (Eburon, Delft)

De Kam, G., 1996, Op grond van beleid. Locaties voor sociale woningbouw, grondbeleid en ruimtelijke spreiding van welstand in en rond Den Haag. (Nationale Woningraad, Almere)

Kingdon, J. W., 1995, Agendas, alternatives and public policies (Harper Collins, New York)

Korthals Altes, W. K. \& Groetelaers, D. A., 2000, "De ontwikkeling van uitbreidingslocaties: context en praktijk" Achtergrondinformatie 35-45

Lefèvre, C., 1998, "Metropolitan government and governance in western countries: a critical review" International Journal of Urban and Regional Research 22 482-506

Linder, S. H. \& Peters, B. G., 1995, The two traditions of institutional designing: dialogue versus decision?, in Ed. D. L. Weimer The two traditions of institutional designing: dialogue versus decision?(Kluwer Academics, Boston) pp 133-158

March, J. G. \& Olsen, J. P., 1989, Rediscovering institutions: the organizational basis of politics (The Free Press, New York)

Van der Meer, J. \& Van Hoek, R. M., 1999, Future governance of city regions: State-ofthe-art in the Netherlands Euricur report, EURICUR (Erasmus University Rotterdam, Rotterdam)

Needham, B., 1997, "Land policy in the Netherlands" Tijdschrift voor Economische en Sociale Geografie $\mathbf{8 8}$ 291-296

Needham, B. \& Louw, E., 2003, "Padafhankelijke bedrijventerreinen" ESB 368-370

Newman, P. \& Thornley, A., 1996, Urban planning in Europe: international competition, national systems \& planning projects (Routledge, London)

North, D. C., 1990, Institutions, institutional change and economic performance (Cambridge University Press, New York) 
Pestman, P., 2001, In het spoor van de Betuweroute: mobilisatie, besluitvorming en institutionalisering rond een groot infrastructureel project (Rozenberg Publishers, Amsterdam)

Schaap, L., 1997, Op zoek naar prikkelende overheidssturing : over autopoiese, zelfsturing en stadsprovincie (Eburon, Delft)

Scharpf, F., 1997, Games real actors play: actor-centered institutionalism in policy research (Westview Press, Boulder CO)

Schattschneider, E. E., 1960, The Semi-Sovereign People (Holt, Rinehart \& Winston, New York)

Schmidt, V. A., 2005, forthcoming, Institutionalism and the state, in Eds. C. Hay, D. Marsh \& M. Lister Institutionalism and the state.(Palgrave, Basingstoke) pp

Schobben, R. J. P., 1995, "De regionale bestuurslaag in Nederland en elders in Europa: een vergelijkende analyse" Bestuurswetenschappen 5 351-372

Toonen, T. A. J., 1998, Provinces versus urban centres. Current developments, background and evaluation of regionalisation in the Netherlands, in Eds. P. Le Galès \& C. Lequesne Provinces versus urban centres. Current developments, background and evaluation of regionalisation in the Netherlands.(Routledge, London) pp 130-149

Webster, C. J. \& Lai, L. W. C., 2003, Property rights, planning and markets: managing spontaneous cities (Edward Elgar, Cheltenham (UK) / Northampton (MA, USA))

Weimer, D. L., 1995, Institutional Design: Overview, in Ed. D. L. Weimer Institutional Design: Overview.(Kluwer Academics, Bostom) pp 1-16

Williamson, O. E., 1985, The economic institutions of capitalism: firms, markets, relational contracting (Free Press, New York)

WRR, 1990, Van de stad en de rand (SDU Uitgeverij, Den Haag)

Zweigert, K. \& Kötz, H., 1987, An Introduction to Comparative Law (Clarendon Press, Oxford) 


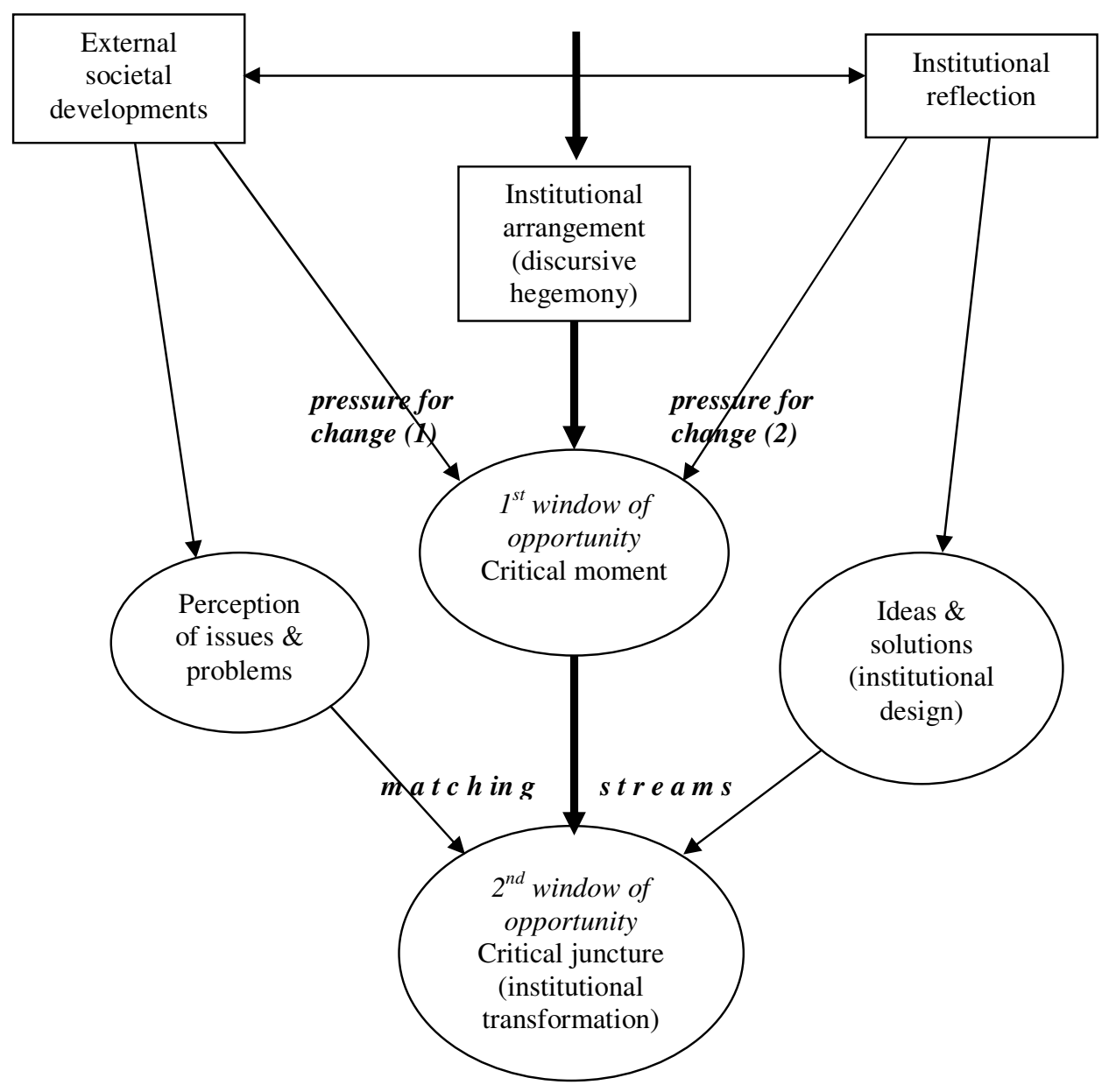

Figure: A model of institutional change 